\title{
Experimental autoimmune arthritis in mice. I. Homologous type II collagen is responsible for self-perpetuating chronic polyarthritis
}

\author{
MARIE-CHRISTOPHE BOISSIER, ${ }^{1}$ XIN-ZHONG FENG, \\ ARMELLE CARLIOZ, ROGER ROUDIER, ', AND CATHERINE FOURNIER
}

From the ${ }^{I}$ INSERM U283 and the ${ }^{2}$ Department of Pathology, Hopital Cochin, 27 rue du Fg St-Jacques, 75674 Paris Cedex 14, France

SUMMARY Immunisation with heterologous type II collagen (CII) induces arthritis in mice of the DBA/1 strain, which is genetically susceptible to this disease. To develop an experimental model of autoimmunity more adequate for the study of human rheumatoid arthritis (RA), DBA/1 mice were injected with $100 \mu \mathrm{g}$ of native CII that had been purified from mouse xiphoid cartilage. About six weeks later the animals developed a chronic progressive polyarthritis involving the four paws but mainly confined to interphalangeal and metatarsophalangeal joints. The evolution of the disease fluctuated between remissions and exacerbations. The initial lesions assessed by clinical observations were more severe when the disease occurred early than in the case of late onset. Interestingly, the incidence of arthritis was clearly preponderant in males, and, moreover, the few female mice which developed arthritis had mild disease states with lower arthritic scores than the males. Varying levels of autoantibodies against mouse CII were found in the sera of immunised animals, regardless of the development of arthritis. These data indicate that the injection of homologous CII into mice caused a polyarthritis that is clinically closer to the human RA than the disease induced with heterologous CII and therefore will represent a useful tool for the study of the self-perpetuating mechanisms that characterise RA.

Key words: murine type II collagen, rheumatoid arthritis, sex linkage, anticollagen autoantibodies.

Rheumatoid arthritis (RA) is characterised by a chronic proliferative synovitis of diarthrodial joints that eventually leads to articular cartilage and bone erosion. The precise nature of the immune reactions that take place in the synovial tissue in RA is poorly understood. It has been postulated that the massive infiltrates of helper $\mathrm{T}$ cells in close contact with HLR-DR $^{+}$synovial stellate cells are mutually stimulatory, supporting the existence of a local selfperpetuating activation. ${ }^{12}$ Moreover, the susceptibility to this autoimmune disease is regulated by major histocompatibility complex genes. Thus the risk of developing RA is associated with DR4 antigens. ${ }^{34}$

In the past, numerous models of experimentally

Accepted for publication 17 March 1987.

Correspondence to Dr Catherine Fournier, INSERM U283, Hôpital Cochin, 27 rue du Fg St-Jacques, 75674 Paris Cedex 14. France. induced arthritis were developed using adjuvants, antigens, or type II collagen (CII) as immunising agents, with a view to analysing the pathogenesis of RA. Since patients suffering from chronic inflammatory arthritis have humoral ${ }^{5-13}$ and cellular ${ }^{1012-16}$ sensitivities to collagen, collagen induced arthritis (CIA) may have relevance to the human disease. First described in rats ${ }^{17} 18$ and then in mice, ${ }^{1920}$ the collagen induced experimental model shares a number of clinical and histological features with RA. ${ }^{21}$ Likewise, susceptibility to CIA is under genetic control in both rats ${ }^{22} 23$ and mice. ${ }^{2024}$ Moreover, the formation of a synovial pannus and the accompanying articular cartilage erosion are two morphological manifestations of CIA. This experimental disease, however, is provoked by injection of a xenogeneic protein probably carrying species specific determinants that may be immunogenic and contribute to the development of the arthritis. 
Therefore, we attempted to induce an experimental autoimmune arthritis (EAA) that would more closely mimic the human RA by injecting native $\mathrm{CII}$ of murine origin into the susceptible $\mathrm{DBA} / 1$ mice.

\section{Materials and methods}

\section{I C E}

DBA/1 mice aged 6 to 17 weeks were obtained from the Institut Pasteur breeding centre (Paris, France). Animals matched for age and sex were used in all experiments.

\section{CARTILAGE COLLAGENS}

Mouse CII was prepared from the xiphoid appendix. ${ }^{17}$ After careful dissection to eliminate fatty tissue and avoid bone contamination the xiphoid cartilages were pulverised in liquid nitrogen and the powder obtained was then washed at $4^{\circ} \mathrm{C}$

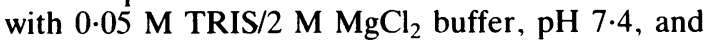
further rinsed twice with distilled water. The residue was solubilised in $0.5 \mathrm{M}$ acetic acid (adjusted to $\mathrm{pH}$ 2.5 by the addition of formic acid), and digestion with pepsin (Sigma, St Louis, Mo, USA) proceeded for $72 \mathrm{~h}$ at $4^{\circ} \mathrm{C}$. After neutralisation and then centrifugation at $20000 \mathrm{~g}$ for $20 \mathrm{~min}$ the undigested residue was treated twice with pepsin under identical conditions. Supernatants from the three extractions were dialysed against $0.05 \mathrm{M}$ TRIS/0.2 M $\mathrm{NaCl}, \mathrm{pH} 7 \cdot 6$, and passed through a column of diethylaminoethyl (DEAE) cellulose. Collagen was then eluted with the same buffer, precipitated by addition of $3 \mathrm{M} \mathrm{NaCl}$, solubilised with $0.5 \mathrm{M}$ acetic acid, and dialysed against $0.01 \mathrm{M} \mathrm{Na} \mathrm{HPO}_{4}$. The precipitate was dissolved in acetic acid, and collagen was again precipitated by adding $1 \mathrm{M} \mathrm{NaCl}$, redissolved in acetic acid, dialysed against $0.1 \mathrm{M}$ acetic acid, and finally lyophilised. The purity of murine CII preparations was verified by the presence of a single band after electrophoresis on polyacrylamide gel.

Native bovine type II collagen was kindly provided by D Herbage (CERAD, Lyon, France).

\section{IMMUNISATION PROCEDURES}

Lyophilised native CII was dissolved in $0 \cdot 1 \mathrm{M}$ acetic acid at $4^{\circ} \mathrm{C}$ and this solution was emulsified with an equal volume of complete Freund's adjuvant (CFA; Gibco Laboratories, New York, USA). Two different immunisation protocols were used: each group was composed of 48 mice including males (M) and females $(F)$. In group I, 14 mice $(6 \mathrm{M}, 8 \mathrm{~F})$ were primed intradermally with $100 \mu \mathrm{g}$ of native mouse CII (in $200 \mu \mathrm{l}$ ) at four to six different sites on the back and were challenged 21 days later with $100 \mu \mathrm{g}$ of native mouse CII in acetic acid, injected intra- peritoneally. As a positive control, $8 \mathrm{M}$ and $6 \mathrm{M} \Xi$ received the same doses of native bovine CII using $\frac{0}{\omega}$ identical immunisation procedures. As negative controls, 10 mice $(5 \mathrm{M}, 5 \mathrm{~F})$ were primed with CFA alone and challenged with acetic acid, and 10 other mice $(5 \mathrm{M}, 5 \mathrm{~F})$ remained untreated. Group II included $13 \mathrm{M}$ and $14 \mathrm{~F}$ injected intradermally with $100 \mu \mathrm{g}$ of native mouse CII in CFA (in $100 \mu \mathrm{l}$ ) into the right hind foot pad. Females, but not males, were boosted intradermally 14 days later with an os additional $50 \mu \mathrm{g}$ of mouse CII in incomplete $\vec{\circ}$ Freund's adjuvant (IFA; Gibco). As controls for the males, $5 \mathrm{M}$ were primed once with bovine $\mathrm{CII}$ and $11 \mathrm{M}$ received CFA alone. Following the same immunisation protocol as that used for the females? injected with mouse CII, $5 \mathrm{~F}$ were injected first with CFA alone and 14 days later with IFA alone.

ARTHRITIS EVALUATION

Animals from both groups were observed daily for $\stackrel{\circ}{3}$ the onset of arthritis, beginning three weeks after $\vec{c}$ priming until they were killed at nine weeks post- $\frac{\mathbb{D}}{8}$ priming for the first group and 24 weeks post- $\frac{\overrightarrow{\mathbb{D}}}{\overrightarrow{0}}$ priming for the second group. The date of disease 3 onset was recorded on a daily basis for individual mice. After clinical examination of the non-injectegl $\overrightarrow{0}$ paws (four limbs for group I and three limbs for group II) the severity of the disease was graded an arthritic index based upon the macroscopic sigas observed (erythema, swelling, distortion of the joints) and calculated by adding the scores of each $\overline{\bar{O}}$ individual joint affected.

Table 1 Incidence of arthritis induced with native? homologous or heterologous type II collagen

\begin{tabular}{|c|c|c|c|c|c|c|c|}
\hline \multirow[t]{3}{*}{ Group } & \multirow[t]{3}{*}{ Sex } & \multicolumn{6}{|c|}{ Incidence of arthritic $n$} \\
\hline & & \multicolumn{2}{|l|}{$C F A$} & \multicolumn{2}{|c|}{ Mouse CII } & \multicolumn{2}{|c|}{ Bovine CII } \\
\hline & & $n$ & $\%$ & $n$ & $\%$ & $n$ & $\%$ \\
\hline \multirow[t]{2}{*}{ I* } & $\mathbf{M}$ & $0 / 5$ & 0 & $5 / 6$ & $83 \cdot 3$ & $8 / 8$ & $100 \cdot 0$ 윽 \\
\hline & F & $0 / 5$ & 0 & $3 / 8$ & $37 \cdot 5$ & $3 / 6$ & $50 \cdot 0$ \\
\hline \multirow[t]{2}{*}{ IIt } & $\mathbf{M}$ & $0 / 11$ & 0 & $13 / 13$ & $100 \cdot 0$ & $5 / 5$ & $100 \cdot 0$ \\
\hline & $\mathbf{F}$ & $0 / 5$ & 0 & $3 / 14$ & $21 \cdot 4$ & $\mathrm{ND} \ddagger$ & ND $N$ \\
\hline
\end{tabular}

${ }^{*}$ Mice from group I were primed with $100 \mu \mathrm{g}$ of native CII (orv acetic acid alone) emulsified in CFA injected intradermally at foun to six sites on the back and were challenged intraperitoneally $2 \mathrm{~kW}$ days later with $100 \mu \mathrm{g}$ of $\mathrm{CII}$ of the same origin as that used for priming (or acetic acid alone).

tMice from group II were injected with $100 \mu \mathrm{g}$ of CII (or acetic aciof alone) in CFA intradermally into the right hind foot pad. Females $\mathbb{\complement}$ but not males, were boosted intradermally with an additional $5(f+$ $\mu \mathrm{g}$ of CII (or acetic acid alone) in IFA 14 days later. $\ddagger \mathrm{ND}=$ not done. 
H IS T O PATH OLOG Y

The animals were killed and the four limbs of all animals (including the non-injected control mice) were dissected out for histological examination. Joints were slowly decalcified for one month and embedded in paraffin blocks. At least five sections ( $5 \mu \mathrm{m}$ thick) were cut along a longitudinal axis, mounted, and stained with haematoxylin and eosin

\section{ANTI-CII ANTIBODY MEASUREMENT}

Mice were bled by retro-orbital puncture on several occasions during the experiments as reported in the text. The individual serum samples were collected, divided into aliquots, and stored at $-70^{\circ} \mathrm{C}$ until they

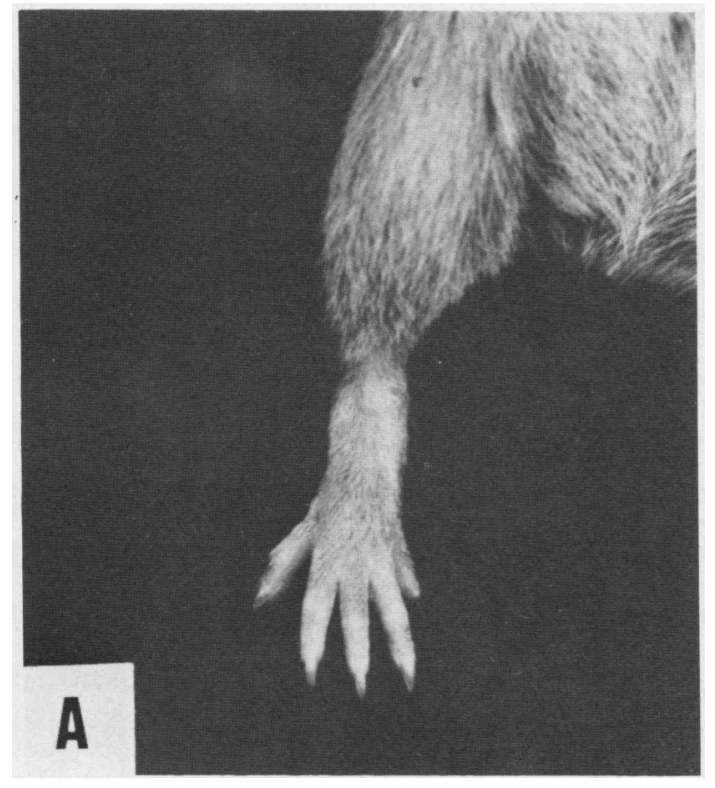
before being evaluated blind.

were tested for antibodies directed against mouse and bovine CII using an enzyme linked immunosorbent assay (ELISA) adapted from Stuart et al. ${ }^{25}$ MicroELISA plates (Nunclon, Roskilde, Denmark) were coated overnight at $4^{\circ} \mathrm{C}$ with $50 \mu \mathrm{l} /$ well of a $10 \mu \mathrm{g} / \mathrm{ml}$ solution of mouse (or bovine) CII in phosphate buffered saline (PBS). After three washes with $0 \cdot 1 \mathrm{M}$ TRIS $/ 0 \cdot 15 \mathrm{M} \mathrm{NaCl}$ containing $0 \cdot 05 \%$ Tween 20, $\mathrm{pH} 7.4$ (TRIS-Tween buffer), the remaining protein binding sites on the plastic were blocked by the addition of $0.25 \%$ bovine serum albumin (Sigma) in PBS for two hours at $4^{\circ} \mathrm{C}$. The plates were then washed three times with TRISTween buffer and $50 \mu \mathrm{l}$ of the serum to be tested (diluted 1:100) was deposited in duplicate wells. Plates were kept overnight at $4^{\circ} \mathrm{C}$, washed three times with TRIS-Tween buffer, then the appropriate dilution of goat antimouse immunoglobulins coupled to alkaline phosphatase (Miles-Yeda Laboratories, Israel) was added to each well. The amount of bound enzyme was measured with $p$ nitrophenol as the chromatogen substrate in a Titertek multiscan spectrophotometer at $405 \mathrm{~nm}$. The results were expressed as optical density (OD) $\times 10^{3}$ in experimental wells minus the background OD obtained in wells in which the CII coating had been omitted.

\section{Results}

INCIDENCE OF ARTHRITIS INDUCED WITH NATIVE HOMOLOGOUS CII

In a first series of experiments mice were primed with $100 \mu \mathrm{g}$ of native mouse CII (or bovine CII as a positive control) and challenged three weeks later with the same dose of respective antigens, as described in 'Materials and methods'. The administration of homologous CII elicited a high incidence of autoimmune arthritis in DBA/1 mice. Interestingly, the males were more susceptible to the

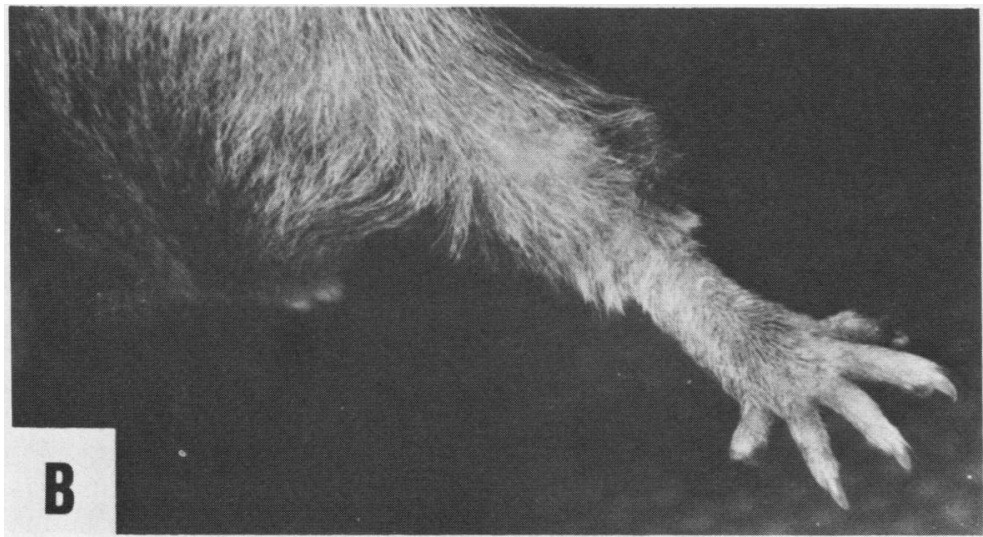

Fig. 1 (A) Hind paw of a control DBA/l mouse injected with $C F A$ and $(B)$ that of an arthritic male mouse eight weeks post-immunisation with native mouse CII. There was diffuse soft tissue swelling and intense erythema of the entire paw with prominent synovitis of the knee, the ankle, and all the metatarsophalangeal and interphalangeal joints. Note the markedly increased thickness of the first, fourth, and fifth toes. 
Table 2 Clinical features of experimental autoimmune arthritis

\begin{tabular}{|c|c|c|c|c|c|}
\hline \multirow[t]{2}{*}{ Group ${ }^{\dagger}$} & \multirow[t]{2}{*}{ Sex } & \multicolumn{2}{|c|}{$\begin{array}{l}\text { Disease onset (days) } \\
\text { for mice injected with: }\end{array}$} & \multicolumn{2}{|c|}{$\begin{array}{l}\text { Arthritic score for } \\
\text { mice injected with: }\end{array}$} \\
\hline & & Mouse CII & Bovine CII & Mouse CII & Bovine CII \\
\hline I & $\begin{array}{l}\mathbf{M} \\
\mathrm{F}\end{array}$ & $\begin{array}{l}41 \cdot 2(2 \cdot 4)^{*} \ddagger \\
49 \cdot 0(0 \cdot 0)^{* *}\end{array}$ & $\begin{array}{l}33.3(1 \cdot 2)^{*} \\
35.6(3 \cdot 7)^{* *}\end{array}$ & $\begin{array}{l}5 \cdot 6(0 \cdot 7) \\
3 \cdot 6(1 \cdot 2)\end{array}$ & $\begin{array}{l}6.7(0.9) \\
3.6(1.6)\end{array}$ \\
\hline II & $\begin{array}{l}\mathrm{M} \\
\mathrm{F}\end{array}$ & $\begin{array}{l}42 \cdot 0(2 \cdot 9) \\
59 \cdot 6(16 \cdot 7)\end{array}$ & $\begin{array}{l}35 \cdot 1(2 \cdot 1) \\
\text { ND }\end{array}$ & $\begin{array}{l}7.3(0.9) \\
4.3(0 \cdot 7)\end{array}$ & $\begin{array}{l}5 \cdot 0(1 \cdot 1) \\
\text { ND }\end{array}$ \\
\hline
\end{tabular}

†For definition of the groups see Table 1 footnotes. $\ddagger$ Statistical analysis using the Mann Whitney test: ${ }^{*} \mathrm{p}<0.05$; ** $\mathrm{p}<0.01$.

Values are mean (SEM).
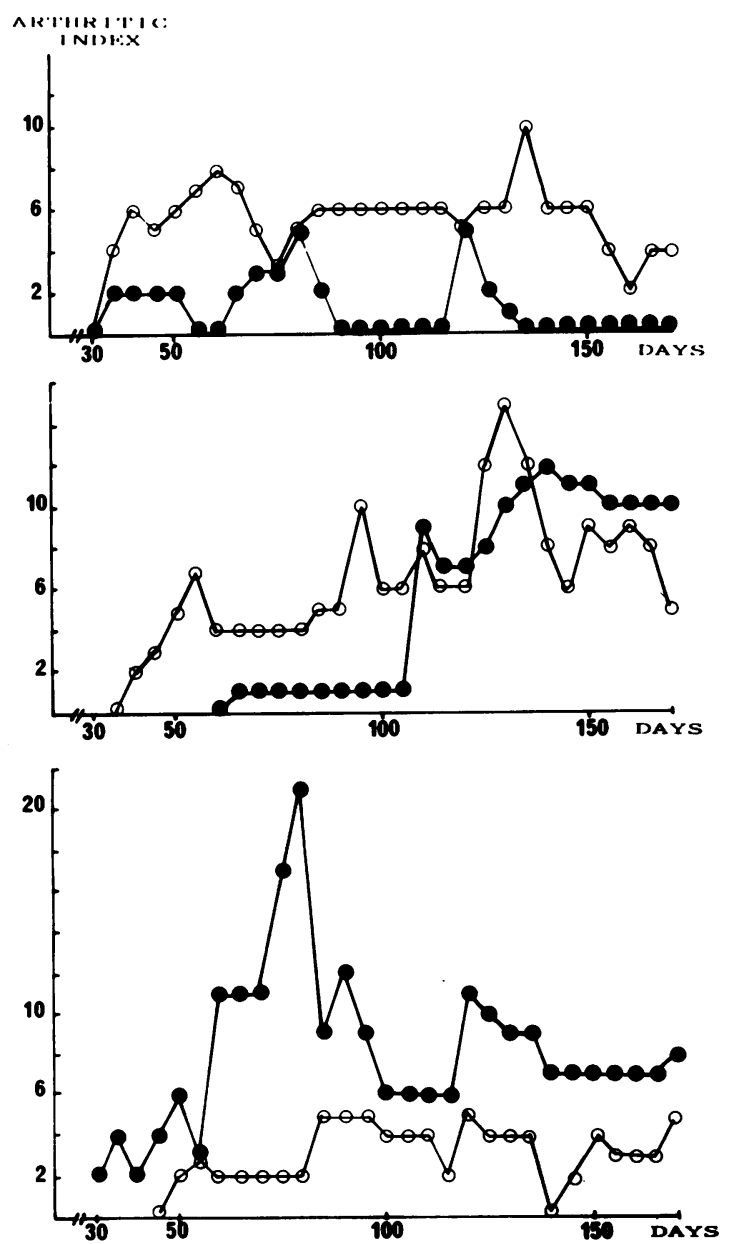

Fig. 2 Time course of clinical features observed in six male mice from group II. induction of EAA regardless of whether they received the homologous or the heterologous protein (Table 1). To confirm the sex linkage of EAA, $\Rightarrow$ in the second series of experiments males were $\stackrel{\oplus}{+}$ immunised only once with native mouse CII, , whereas females were injected twice. Despite the 흠 booster injection, most of the females remained $\frac{\text { क }}{7}$ resistant to the induction of the disease, whereas all $\stackrel{\Phi}{\complement}$ the males became arthritic (Table 1). When the results of both groups of mice were combined and $\overrightarrow{0}$ analysed by the $\chi^{2}$ test the preponderance of EAA was significantly higher for males than for femles $\vec{\omega}$ $(\mathrm{p}<0.001)$.

CLINICAL COURSE OF EAA
All mice were clinically examined for evaluation of $\frac{\vec{\sigma}}{0}$ their disease, beginning three weeks post-priming 6 with CII, until nine weeks for group I, and 24 weeks 6 for group II. Control mice injected with CFA alone, 0 or non-injected controls, were simultaneously ex- $\triangle$ amined and did not show any macroscopic signs of $\overrightarrow{C S}$ arthritis. Fig. 1 compares the hind paw of a male $\frac{\mathbb{O}}{O}$ mouse that developed a severe autoimmune arthritis $\mathbb{\mathbb { D }}$ with a non-arthritic limb from a control mouse.

As shown in Table 2 the onset of arthritis was significantly delayed when the mice received hom $8 \overrightarrow{0}$ logous CII in comparison with immunisation wi heterologous CII. Evaluation of the arthritic sco showed that the disease severity was not signifir cantly different in the group of male mice injected with mouse CII than in those injected with bovine CII (Table 2). In the latter case the disease $\frac{0}{8}$ developed explosively one month after the adminis- 0 tration of the xenogeneic protein and the maximum $\overrightarrow{\vec{O}}$ severity was rapidly attained. After the acute phase, 3 exacerbation of the arthritis did not occur spontaneously. In contrast, the disease provoked by the? mouse CII injection was much more progressive and its evolution fluctuated between remissions and $\bar{O}$ exacerbations even after a single injection of CII. 을 Fig. 2 illustrates the development of clinical arthritis in six individual male mice from group II. Typically, interphalangeal and metatarsophalangeal joints were gradually and chronically affected. $\frac{\text { ? }}{5}$ Acute symptoms generally disappeared rapidly and then recurred several weeks later in the same or other joints. During the quiescent period of the N arthritis the affected joints never completely recovered from the inflammation, therefore when the $O$ disease relapsed the primarily affected joints $\omega$ showed additional lesions. In comparison with the males, the few females that developed the diseaseo had disparate times of onset but always showed a mild disease form (Table 2).

Interestingly, we found an inverse relationship between the severity of the primary lesions and the $\frac{\vec{\Phi}}{\mathrm{D}}$ 
Arthritic index

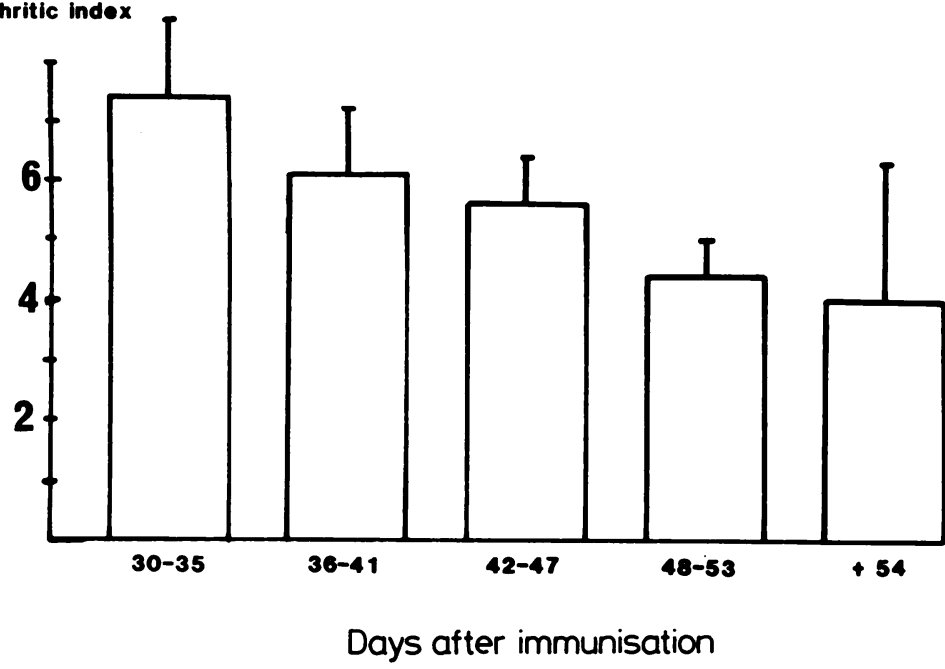

Fig. 3 Relationship between the time of onset and the severity of the first phase of the disease.

time of disease onset (Fig. 3). Thus the earlier the first macroscopic signs of arthritis appeared, the higher the arthritic scores observed during the initial phase of the disease.

HISTOLOGICAL STUDIES

Histological sections were performed at the time of death on the four paws for mice from group I, and on the three non-injected paws for animals from group II. Sections of the limbs that were injected with the antigen were examined separately and were always characterised by a dense inflammatory cell infiltrate beneath the hyperplastic synovial cells, around the capillary blood vessels and often extending more deeply into the adipose tissue. Conversely, in the non-injected paws a continuous spectrum of synovitis was observed, the histological lesions were usually asymmetrical and involved more freqently, and more intensely, the distal rather than the proximal joints. All the affected joints showed synovial proliferation with excessive convolution and increased degrees of multilayering (Fig. 4A). In many cases synovial cells had a greater amount of cytoplasm, became cuboidal, and were dissociated by an intrasynovial oedema (Fig. 4B). Frequently, adjacent to the abnormalities of the synovial lining cells, the sections showed a single layer of flat synovial cells in a different area of the same joint. In some instances the mitosis of synovial cells was accompanied by the deposition of fibrin-like material on the synovium.

The histological lesions observed were consistently milder in mice injected with homologous CII

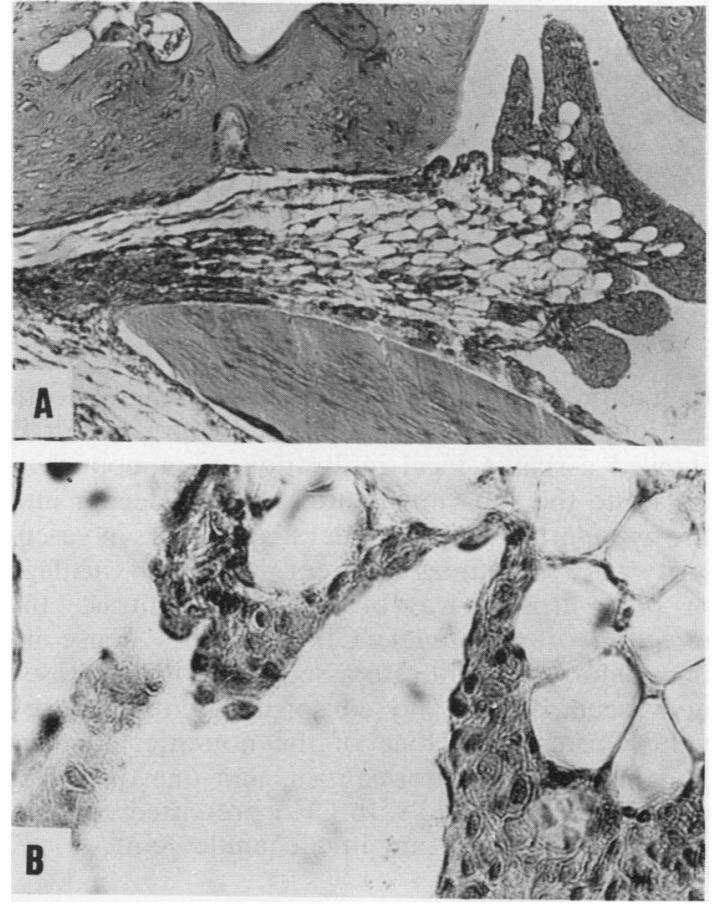

Fig. 4 Haematoxylin and eosin stained sections of various joints from mice injected with mouse CII.

(A) Metacarpophalangeal joint from a paw of a male mouse showing inflammatory villi with an intense synovial proliferation. (B) Tarsal joint from another male mouse showing details of hyperplastic synovium presenting increased amounts of cytoplasm in the synovial cells. 


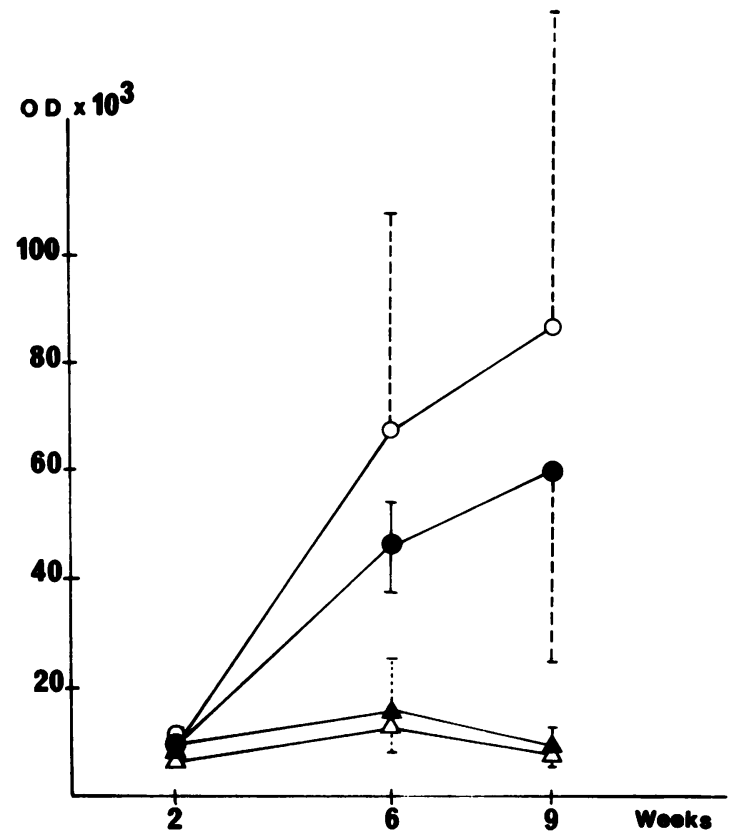

Fig. 5 Kinetics of autoantibody production in mice from group $I$. The serum samples were individually tested for their reactivity against mouse CII and means (SEM) were calculated for the males (-) or the females ( $\left.\mathrm{O}_{-} \mathrm{O}\right)$ immunised with mouse $\mathrm{CII}$ and for

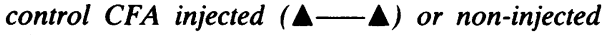
$(\triangle \longrightarrow \triangle)$ mice.

than in those given bovine CII. At the time of death the joints from animals immunised with mouse CII showed a sparse focal infiltration of mononuclear cells into the subsynovial area or even deeper into the hypodermic tissue. Moderate increases in vascularity were sometimes apparent. No sign of cartilage or bone erosion was observed. In contrast, the injection of xenogeneic CII induced a dense inflammatory cell infiltrate associated with increased neovascularisation and conspicuous inflammatory villus formations. None of the non-injected mice had histological abnormalities, and one out of 26 control mice injected with CFA presented a hyperplasia of the synovium in the ankle joint.

ANALYSIS OF THE HUMORAL RESPONSE TO CII

Mice immunised with mouse CII, bovine CII, those injected with CFA alone, or naive mice were bled at various times after the second week postimmunisation until death. The individual serum samples collected were analysed for the presence of
anti-CII antibodies by ELISA. Figs 5 and 6 show the $\square$ levels of antibodies directed against mouse CII $\stackrel{\text { ? }}{\text {. }}$ obtained respectively in groups I and II. Although $\vec{F}$ highly variable titres of circulating antibodies were found, all the mice injected with mouse CII developed a humoral response, whereas the serum $\frac{\bar{\sigma}}{\bar{D}}$ samples from CFA injected mice or naive mice $\vec{\odot}$ remained negative throughout the study. Interestingly, there was no relation between the levels of autoantibodies and the development of arthritis in $\vec{\circ}$ either group of mice. Hence the females responded as well or even better than the males, irrespective of $\vec{\omega}$ the presence of clinical signs of arthritis (Fig. 5). We observed a regular increase of antimouse CII IgGō until the ninth week in group I (Fig. 5), whereas in $+\vec{\sigma}$ group II the males showed a progressive decline inco their antibody titres from the fifth to the fifteentho week post-immunisation (Fig. 6). It is probable that ${ }^{-}$ the booster intraperitoneal injection given threes weeks after priming to the mice in group I, but not ${ }^{-}$ to the males in group II, delayed and enhanced the ${ }_{\infty}$ humoral response. Similarly, group II females that were challenged with mouse CII emulsified in IFA 3 showed very high autoantibody levels which peaked 13 weeks after priming (Fig. 6).

All the serum samples from the mice in group were tested for their cross reactivities with mouse. $v$ and bovine CII. Several observations can be ferred from the results shown in Fig. 7. Firstly, thes injection of heterologous $\mathrm{CII}$ elicited a humoral response that was at least 10 -fold higher than that induced by homologous CII. Secondly, the antibody secreted in response to the autoantigen increased $\underset{+}{\rightarrow}$ until the death of the animals at nine weeks. Thirdly, despite an important cross reactivity for CII of both origins the sera reacted best with the immunising protein in comparison with the other one. In other words, both males and females receiving mouse $\mathrm{CII}_{\alpha}^{2}$ developed higher titres of antibodies reacting witho mouse CII than with bovine CII, and vice versa,

\section{Discussion}

This paper describes the induction of an autoim-? mune arthritis in mice which mimics the clinical $\frac{D}{5}$ features of human RA. By use of immunisation with a purified homologous protein, thereby avoiding $N$ immune reactivity against xenogeneic determinants, $N$ we were able to analyse the disease caused by an autoantigen. The most prominent feature that dis- $\omega$ tinguishes our model from the arthritis induced with? heterologous CII is the fluctuation between remis $\frac{0}{C}$ sions and exacerbations observed during the course of the disease. Thus in contrast with the bovine $\mathrm{CII}^{+}$ induced arthritis, which develops explosively one ${ }_{\overline{0}}^{0}$ month after immunisation and never relapses after $\frac{\text { D }}{\mathrm{D}}$ 
OD $\times 10^{3}$

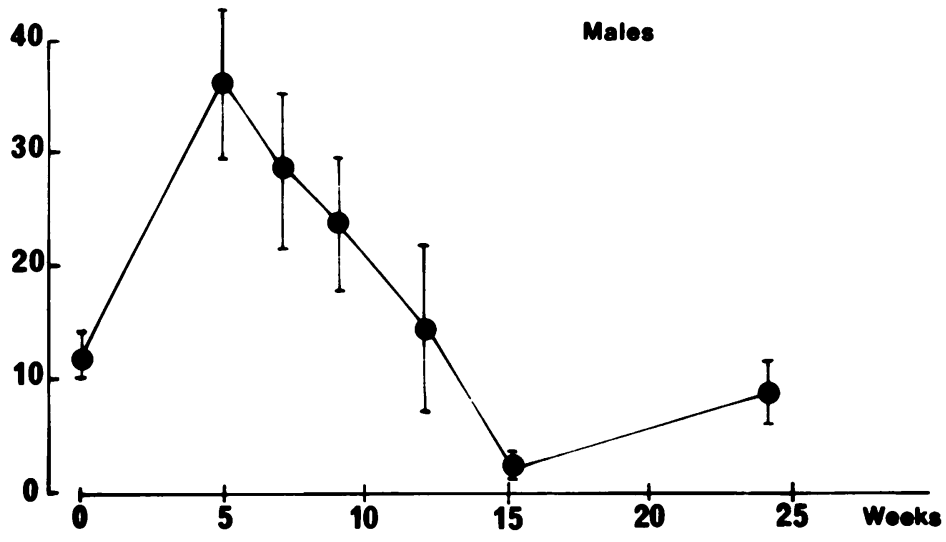

Fig. 6 Kinetics of antimouse CII IgG produced after immunisation with homologous CII in mice from group II. The upper part of the figure shows the response of the males injected once with mouse CII

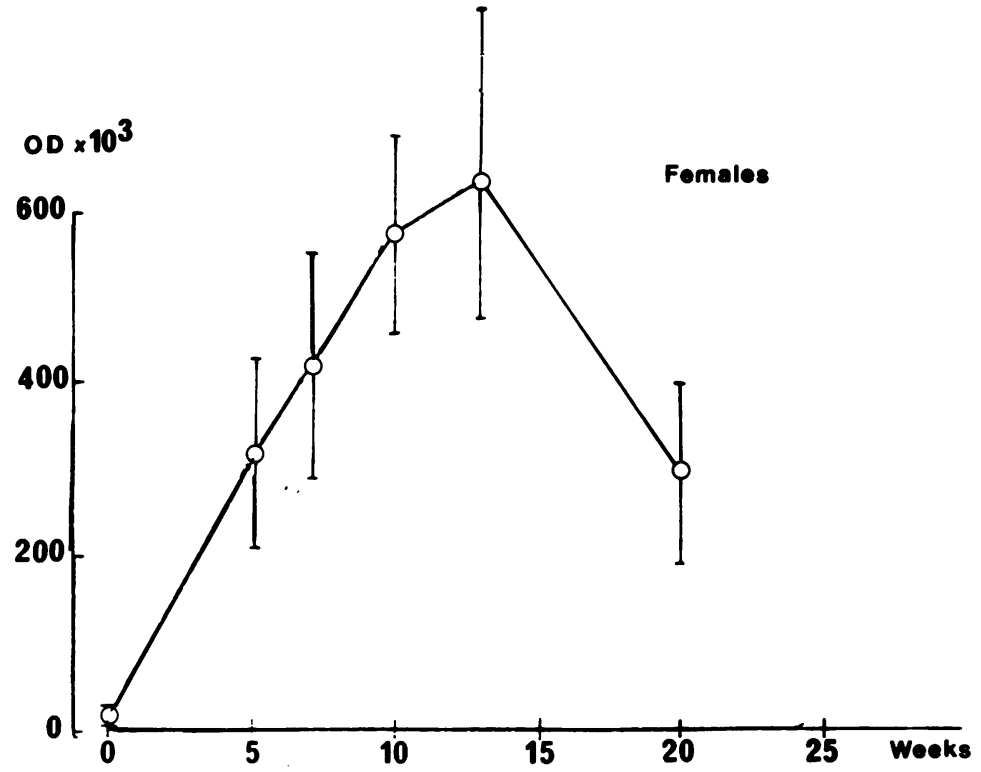
(-) and the lower part reports the autoantibody production by the females injected twice with mouse CII (O-O). (For details of the immunisation procedure see 'Materials and methods'.)

remission, the first macroscopic signs of EAA occurred later and progressively. After an acute inflammatory episode the affected joints gradually and partially recovered, and several days or weeks later the disease recurred affecting the same or other joints. In a recent study Holmdahl et al reached identical conclusions, although their overall incidence of arthritis (30\%) after administration of homologous CII to male and female mice was lower than in our experiments $(58.5 \%$ in the two groups combined). ${ }^{26}$ Since the regimen for the induction of arthritis differed in the two studies it is possible that the immunisation protocol represents a critical point for the development of the disease. With respect to the histological features of EAA, cellular hyperplasia of the synovial membrane was always observed in the affected joints, even though the pathological changes were moderate, and the inflammatory cell infiltrate was less intense in the polyarthritis induced with the homologous than with the heterologous CII. It is possible that more severe histological lesions may be observed at the initiation or during 

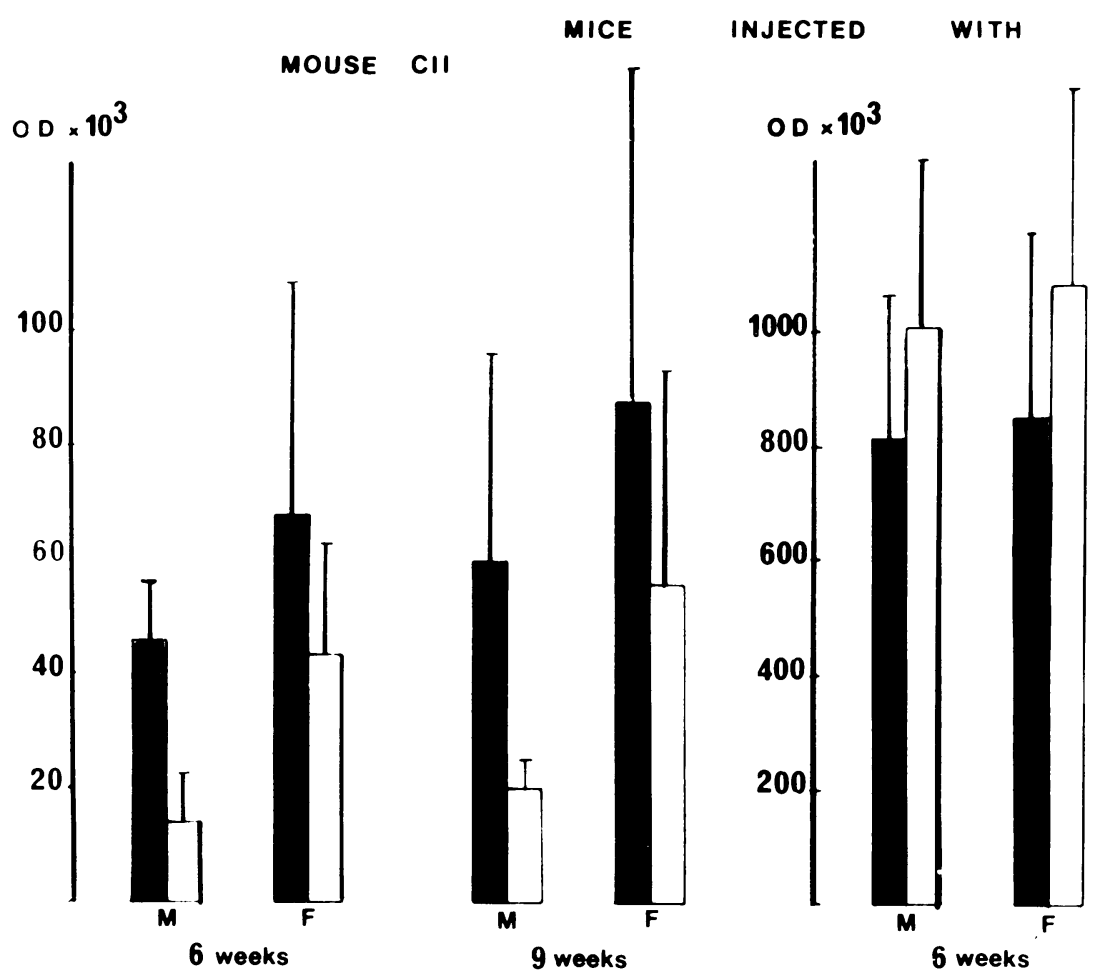

BOVINE CII

Fig. 7 Cross reactivity of the serum samples from group I mice immunised with mouse CII (left side) or bovine (FIO (right side). Individual serum samples from males $(M)$ and females $(F)$ were tested for their reactivities against mouse' CII ( $)$ or bovine $(I I, \square)$ six and nine weeks post-immunisation.

the course of the disease, which then regressed since, at the time of deaths animals showed only mild synovitis. This possibility is under investigation in our laboratory.

Interestingly, in our model the clinical patterns and the kinetics were highly variable from one mouse to another. Such clinical evolution resembles that of human RA, and therefore our experimental model would be a useful tool for the study of the self-perpetuating mechanisms that characterise RA. In contrast with the human disease, however, the females were significantly less susceptible to the induction of arthritis than were the males. In addition, the few females that developed arthritis after immunisation with homologous CII showed mild disease states. These findings are reminiscent of ankylosing spondylitis. The sex linkage of EAA that we observed is consistent with a recent report ${ }^{27}$ but is not supported by findings described earlier in female rats ${ }^{17}{ }^{18}$ or in mice. ${ }^{20}$ It is unlikely that the weak susceptibility of females to EAA induction is related to the amount of autoantigen injected, given that a booster injection of mouse CII in IFA failed to augment the incidence of EAA, while it increased the levels of autoantibodies produced. Rather, it seems that female sex hormones exert a suppressive응 effect on the induction of autoimmune arthritis.

A critical role for antibodies against native $\mathrm{CII}$ in the initiation of CIA has been suggested by severas. investigators who demonstrated that the severity of the experimental disease was associated with a higho humoral response to the immunising antigen. 1 . $25^{\circ}$ "S In addition, anti-CII IgG either purified from arthritic animal serum samples ${ }^{30}$, or monoclona每 antibodies ${ }^{3+35}$ were shown to be active in transfer-o ring the disease. In the present study we found highly? variable amounts of antibodies directed againsto homologous CII, which did not correlate with the arthritic status of the mice. Indeed, the kineticos studies performed on our two groups of micen showed that the males secreted low amounts of specific antibodies, which increased to reach a peak ${ }_{\sigma}^{\omega}$ five to seven weeks after immunisation and then progressively declined. In contrast. both arthritic and non-arthritic females produced higher levels of anti-CII IgG than did the males. Our findings that mice developed a humoral response to CII regard-o less of their arthritic status argue against an antibody 
mediated pathogenesis when the immunising protein is derived from mouse cartilage. At present we cannot rule out the possibility that the disease is related to the secretion of particular IgG subclass autoantibodies, but is not influenced by other isotypes. Evidence suggesting that $\mathrm{IgG} 2 \mathrm{a}$ autoantibodies are more pathogenic than other anti-CII isotypes has been reported for the arthritis induced by heterologous CII injection. ${ }^{31} 36$ This hypothesis is presently under investigation in our laboratory.

An alternative possibility regarding a potential role of type II collagen specific autoantibodies concerns the existence of different epitopes on the molecule. There is increasing evidence that the injection of pepsin solubilised CII provokes a diversity of anti-CII antibodies, some of which are directed against arthritogenic epitopes, whereas others recognise antigenic epitopes. ${ }^{37} 38$ Indeed, we, and others, ${ }^{27}$ have provided evidence that CII of xenogeneic origin induced considerably higher titres of anti-CII antibodies than did the homologous protein. This observation may reflect the existence of one or several species specific epitopes on the collagen molecule that trigger the autoimmune reactivity. Thus the susceptibility to collagen arthritis was shown to be under the control of different immune response genes according to the origin of the CII,${ }^{24}{ }^{37}$ a finding that exemplifies antigenic differences between species. The important cross reactive capacity of the antisera to bovine and mouse collagen implies that the collagen molecules from both species share immunogenic determinants. The consistently higher humoral response against the immunising protein than against the CII of the other origin supports the existence of at least one species restricted epitope.

In the light of these interpretations the failure of female mice to develop arthritis after injection of homologous CII, despite a strong humoral response, may be explained in terms of unresponsiveness to the mouse specific arthritogenic epitope(s), due either to a sex hormone linked negative control of antigen recognition ${ }^{28}$ or to an antibody mediated suppressive mechanism. ${ }^{39-41}$ Additional work is needed to elucidate this alternative hypothesis.

The authors wish to thank Dr D Herbage for generously providing the bovine type II collagen. They are indebted to $\mathrm{Mr} \mathrm{J}$ L Olivier for preparing mouse type II collagen, and to $\mathrm{Mr} \mathrm{J}$ C Mussard and Mrs $C$ Girardot for their excellent technical assistance. They acknowledge Ms J Jacobson for her editorial help and Mrs J Decaix for typing the manuscript. This work was supported by the French Medical Research Council, INSERM, and the French Fund for Rheumatology Research.

\section{References}

I Janossy G, Duke O, Poulter L W, Panayi G, Bofill M, Goldstein G. Rheumatoid arthritis: a disease of T-lymphocyte/ macrophage immunoregulation. Lancet 1981; ii: 839-42.
2 Klareskog L, Forsum U, Scheynius A, Kabelitz D, Wigzell H. Evidence in support of a self-perpetuating HLA-DR-dependent delayed-type cell reaction in rheumatoid arthritis. Proc Natl Acad Sci USA 1982; 79: 3632-6.

3 Stasny P. Association of the B cell alloantigen DRW4 with rheumatoid arthritis. $N$ Engl J Med 1978; 298: 869-71.

4 Panayi G S, Wooley P H, Batchelor J R. Genetic basis of rheumatoid disease: HLA antigens, disease manifestations, and toxic reactions to drugs. $\mathrm{Br}$ Med $J$ 1978; ii: 1326-8.

5 Steffen C. Timpl R. Antigenicity of collagen and its application in the serological investigation of rheumatoid arthritis scra. Int Arch Allergy Appl Immunol 1980; 22: 333-49.

6 Michaeli D. Fudenberg $\mathrm{H} \mathrm{H}$. The incidence and antigenic specificity of antibodies against denatured human collagen in rheumatoid arthritis. Clin Immunol Immunopathol 1974: 2: 153-9.

7 Cracchiolo A, Michaeli D. Goldberg L S, Fundenberg H H. The occurrence of antibodies to collagen in synovial fluids. Clin Immunol Immunopathol 1975; 3: 567-74.

8 Andriopoulos N A. Mestecky J. Miller E J, Bradley E L. Antibodies to native and denatured collagens in sera of patients with rheumatoid arthritis. Arthritis Rheum 1976; 19: 613-7.

9 Menzel J. Steffen C, Kolarz G, Kojer M. Smolen J. Demonstration of anticollagen antibodies in rheumatoid arthritis synovial fluids by ${ }^{14} \mathrm{C}$-radioimmunoassay. Arthritis Rheum 1978; 21: 243-8.

10 Trentham D E, Dynesius R A, Rocklin R E, David J R. Cellular sensitivity to collagen in rheumatoid arthritis. $N$ Engl J Med 1978; 299: 327-32.

11 Clague R B, Shaw M J, Holt P J L. Incidence of serum antibodies to native type I and type II collagens in patients with inflammatory arthritis. Ann Rheum Dis 1980; 39: 201-6.

12 Trentham D E, Belli J A, Anderson R J, et al. Clinical and immunologic effects of fractionated total lymphoid irradiation in refractory rheumatoid arthritis. $N$ Engl $J$ Med 1981; 305: 976-82.

13 Trentham D E. Kammer G M, McCune W J, David J R. Autoimmunity to collagen: a shared feature of psoriatic and rheumatoid arthritis. Arthritis Rheum 1981; 24: 1363-9.

14 Smolen J S. Menzel E J, Scherak O, et al. Lymphocyte transformation to denatured type I collagen and B lymphocyte alloantigens in rheumatoid arthritis. Arthritis Rheum 1980; 23: 424-32.

15 Stuart J M. Postlethwaite A E. Kang A H, Townes A S. Cellmediated immunity to collagen in rheumatoid arthritis and other rheumatic diseases. Am J Med 1980; 69: 13-18.

16 Solinger A M, Bhatnagar R, Stobo J D. Cellular, molecular, and genetic characteristics of $T$ cell reactivity to collagen in man. Proc Natl Acad Sci USA 1981; 78: 3877-81.

17 Trentham D E, Townes A S, Kang A H. Autoimmunity to type II collagen: an experimental model of arthritis. $J$ Exp Med 1977; 146: 857-68.

18 Stuart J M, Cremer M A. Kang A H. Townes A S. Collageninduced arthritis in rats: evaluation of early immunologic events. Arthritis Rheum 1979; 22: 1344-51.

19 Courtenay J S, Dallman M J, Dayan A D. Martin A, Mosdale B. Immunisation against heterologous type II collagen induces arthritis in mice. Nature 1980; 283: 666-8.

20 Wooley P H, Luthra H S, Stuart J M, David C S. Type II collagen induced arthritis in mice. I. Major histocompatibility complex (I region) linkage and antibody correlates. J Exp Med 1981; 154: 688-700.

21 Trentham D E. Collagen arthritis as a relevant model for rheumatoid arthritis: evidence pro and con. Arthritis Rheum 1982; 25: 911-6.

22 Griffiths M M. Eichwald E J. Martin J H, Smith C B, DeWitt $\mathrm{C} \mathrm{W}$. Immunogenetic control of experimental type II collageninduced arthritis. I. Susceptibility and resistance among inbred strains of rats. Arthritis Rheum 1981; 24: 781-9. 
23 Griffiths M M. DeWitt C W. Immunogenetic control of experimental collagen-induced arthritis in rats. II. ECIA susceptibility and immune response to type II collagen (CALF) are linked to RT1. J Immunogenet 1981; 8: 463-70.

24 Wooley P H. Dillon A M, Luthra H S. Stuart J M. David C S. Genetic control of type II collagen induced arthritis in mice. Factors influencing disease susceptibility and evidence for multiple MHC-associated gene control. Transplant Proc 1983: 15: $180-5$.

25 Stuart J M, Townes A S, Kang A H. Nature and specificity of the immune response to collagen in type II collagen induced arthritis in mice. J Clin Invest 1982; 69: 673-83.

26 Holmdahl R, Jansson L. Larsson E. Rubin K. Klareskog L. Homologous type II collagen induces chronic and progressive arthritis in mice. Arthritis Rheum 1986; 29: 106-13.

27 Holmdahl R, Jansson L. Gullberg D, Rubin K. Forsberg P O. Klareskog L. Incidence of arthritis and autoreactivity of anticollagen antibodies after immunization of $\mathrm{DBA} / 1$ mice with heterologous and autologous collagen II. Clin Exp Immunol 1985; 62: 639-46.

28 Holmdahl R, Jansson L, Andersson M. Female sex hormones suppress development of collagen induced arthritis in mice. Arthritis Rheum 1986: 29: 1501-9.

29 Morgan K. Clague R B. Shaw M J. Holt P J L. Native type II collagen-induced arthritis in the rat. I. Incidence and humoral response to collagen. Ann Rheum Dis 1980; 39: 285-90.

30 Stuart J M, Cremer M A, Townes A S, Kang A H. Type II collagen-induced arthritis in rats: passive transfer with serum and evidence that IgG anticollagen antibodies can cause arthritis. J Exp Med 1982; 155: 1-16.

31 Stuart J M. Dixon F J. Serum transfer of collagen induced arthritis in mice. $J$ Exp Med 1983; 158: 378-92.

32 Kerwar S S, Englert M E. Reynolds R A. et al. Type II collagen induced arthritis: studies with purified anti-collagen immunoglobulin. Arthritis Rheum 1983: 26: 1120-31.

33 Takagishi K, Kaibara N, Hotokebuchi T. Arita C, Morinaga M.
Arai K. Serum transfer of collagen arthritis in congenitally athymic nude rats. $J$ Immunol 1985; 134: 3864-7.

34 Hirofuji T, Kakimoto K. Hori H, et al. Characterization of monoclonal antibody specific for human type II collagen $\overline{\bar{\sigma}}$ possible implication in collagen-induced arthritis. Clin Exp Immunol 1985; 62: 159-66.

35 Holmdahl R, Rubin K. Klareskog L. Larsson E. Wigzell H. 을 Characterization of the antibody response in mice with type II $\bar{\Phi}$ collagen induced arthritis using monoclonal anti-type II colla- $\mathbb{D}$ gen antibodies. Arthritis Rheum 1986; 29: 400-10.

36 Watson W C. Townes A S. Genetic susceptibility to murine collagen Il autoimmune arthritis. Proposed relationship to the IgG2 autoantibody subclass response, complement $\mathrm{C} 5$, major $\bigcirc$ histocompatibility complex (MHC) and non-MHC loci. $J$ Exp Med 1985; 162: 1878-91.

37 Wooley P H, Luthra H S. Griffiths M M. Stuart J M. Huse A. David C S. Type II collagen-induced arthritis in mice. IV. Variations in immunogenetic regulation provide evidence for multiple arthritogenic epitopes on the collagen molecule. $J_{\overparen{D}}^{+}$ Immunol 1985; 135: 2443-51.

38 Terato K. Hasty K A. Cremer M A, Stuart J M. Townes A S, Kang A H. Collagen-induced arthritis in mice. Localization of an arthritogenic determinant to a fragment of the type II $\mathrm{O}$ collagen molecule. J Exp Med 1985; 162: 637-46.

39 Staines N A. Hardingham T. Smith M, Henderson B. Collageninduced arthritis in the rat: modification of the immune and $S$ arthritic responses by free collagen and immune anticollageno antiserum. Immunology 1981; 44: 737-44.

40 Wooley P H, Luthra H S, Krco C J, Stuart J M, David C S.J Type II collagen-induced arthritis in mice. II. Passive transfer and suppression by intravenous injection of anti-type II collagen antibody or free native type II collagen. Arthritis Rheum 1984: $\overrightarrow{0}$ 27: $1010-7$

41 Englert M E, McReynolds R A, Landes M J, Oronsky A , Kerwar S S. Pretreatment of rats with anticollagen IgG renders them resistant to active type II collagen arthritis. Cell Immuño 1985: 90: 258-66.

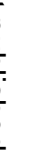

